\title{
Prediction of salt balances in irrigated soils along the lower Vaal River, South Africa
}

\author{
LD van Rensburg*, MG Strydom, CC du Preez, ATP Bennie, PAL le Roux and JP Pretorius \\ Department of Soil, Crop and Climate Sciences, University of the Free State, PO Box 339, Bloemfontein 9300, South Africa
}

\begin{abstract}
In arid and semi-arid regions irrigation tends to degrade soil and water quality through salt accumulation with devastating effects on some crops. This is, according to irrigators, also the case along the lower Vaal River in South Africa. Properly calibrated and tested salinity models could assist the agricultural community in improving salinity management under irrigation.

This paper reports on, firstly, salt balances of soils in this region being irrigated for different time periods, and secondly, salt content changes that can be expected as a consequence of future irrigation. Two empirical models, viz. a general and specific salt-balance model were used together with existing water- and soil-quality data to generate such information. The soils selected for this study had been irrigated for periods of between 17 to 53 years. Over these periods addition of salts as a result of farming practices varied between 79 and $280 \mathrm{t}^{-h} \mathrm{a}^{-1}$, with irrigation water being the major contributor. Between $78 \%$ to $87 \%$ of the salts added to the soils had been leached from the root zone

Despite these large amounts of salts that have been removed, certain irrigation practices have promoted the buildup of salts in some of the soils. The freely drained sandy soils irrigated by centre pivot are of particular interest. Poor management of this system can reduce crop yields. On account of inadequate leaching salts are building up to levels that impair the potential evapotranspiration level of maize. Predictions also show that irrigation should rather be withdrawn from soils with poor internal drainage properties, such as the Arcadia soil at Spitskop. In contrast, flood irrigation on certain duplex soils, such as the Valsrivier at Vaalharts, with relatively good internal drainage properties, can improve their quality.
\end{abstract}

Keywords: drained soils, root zone, soil quality, undrained soils, water quality

\section{Introduction}

It is known that in arid and semi-arid regions irrigation tends to degrade soil and water quality through salt accumulation (Flowers and Yeo, 1986). Most irrigated crops are non-halophytes, which are affected by salt stress and need to be managed accordingly. Properly calibrated and tested salinity models could help the agricultural community to improve salinity management under irrigation.

A vast number of salinity models have been developed over the past 2 decades. Wagenet and Hutson (1987) encouraged researchers to understand the aim of modelling, because a lack of appreciation for different modelling approaches has caused confusion and disarray in modelling efforts. Models can broadly be categorised into two groups according to the purpose for which they were developed (Jones et al., 1987).

The $1^{\text {st }}$ group of models aim to provide a better understanding of the dynamic nature of the biological, chemical and physical environment in which crops grow and are therefore process based. These models vary widely in their conceptual approaches and degree of complexity and are strongly influenced by environmental factors as well as the experience and bias of their developers (Clarke, 1973; Addiscot and Wagenet 1985; Wagenet and Rao, 1990). A short list of such models include MINEQL (Westall et al., 1976), EQ3/NR (Wolery, 1983), MINTEQ (Felmy et al., 1984), SHARON (De Rooy,

\footnotetext{
* To whom all correspondence should be addressed.

용 +27 51 401-2957; fax: +27 51 401-2212;

e-mail: vrensbl.sci@ufs.ac.za

Received 10 July 2007; accepted in revised form 13 November2007.
}

1991), LEACHM (Wagenet and Hutson, 1987), SWIM (Verburg et al., 1996), SOWATSAL (Hanks et al., 1991) and SWB (Barnard et al., 1997). These process-based models can be used to extrapolate results over non-related sites when properly calibrated and tested.

The $2^{\text {nd }}$ group of models aim towards the prediction of the system's behaviour to be applied in improving the management thereof and are therefore problem orientated. Most of the empirical models fall in this category. Examples of such models are the equation for calculating the leaching requirement which had been applied in the Coachella Valley of California (Reeves, 1957) and the salt regime equation of Szabolcs (1986). It is also possible to calculate the accumulation of salts in soil using assumptions based on the mass balance equation of Aragües (1996). These empirical models have the disadvantage that they are site specific, which can restrict the extrapolation of results.

The aim of this paper is to present calculated salt balances of soils along the lower Vaal River in South Africa that had been irrigated for different time periods, and to predict salt content changes expected in these soils as a consequence of future irrigation.

\section{Material and methods}

The location of the study area within South Africa is shown in Fig. 1. In the lower Vaal River, starting at the Bloemhof Dam downstream to the confluence with the Orange River, water quality is influenced largely by inflows from other rivers. For this study the lower Vaal River was therefore divided into four segments, namely V1: from Bloemhof Dam, downstream to the Vaalharts Weir near Warrenton; V2: from Vaalharts Weir, downstream to the Vaal-Harts confluence at Delportshoop; V3: from 


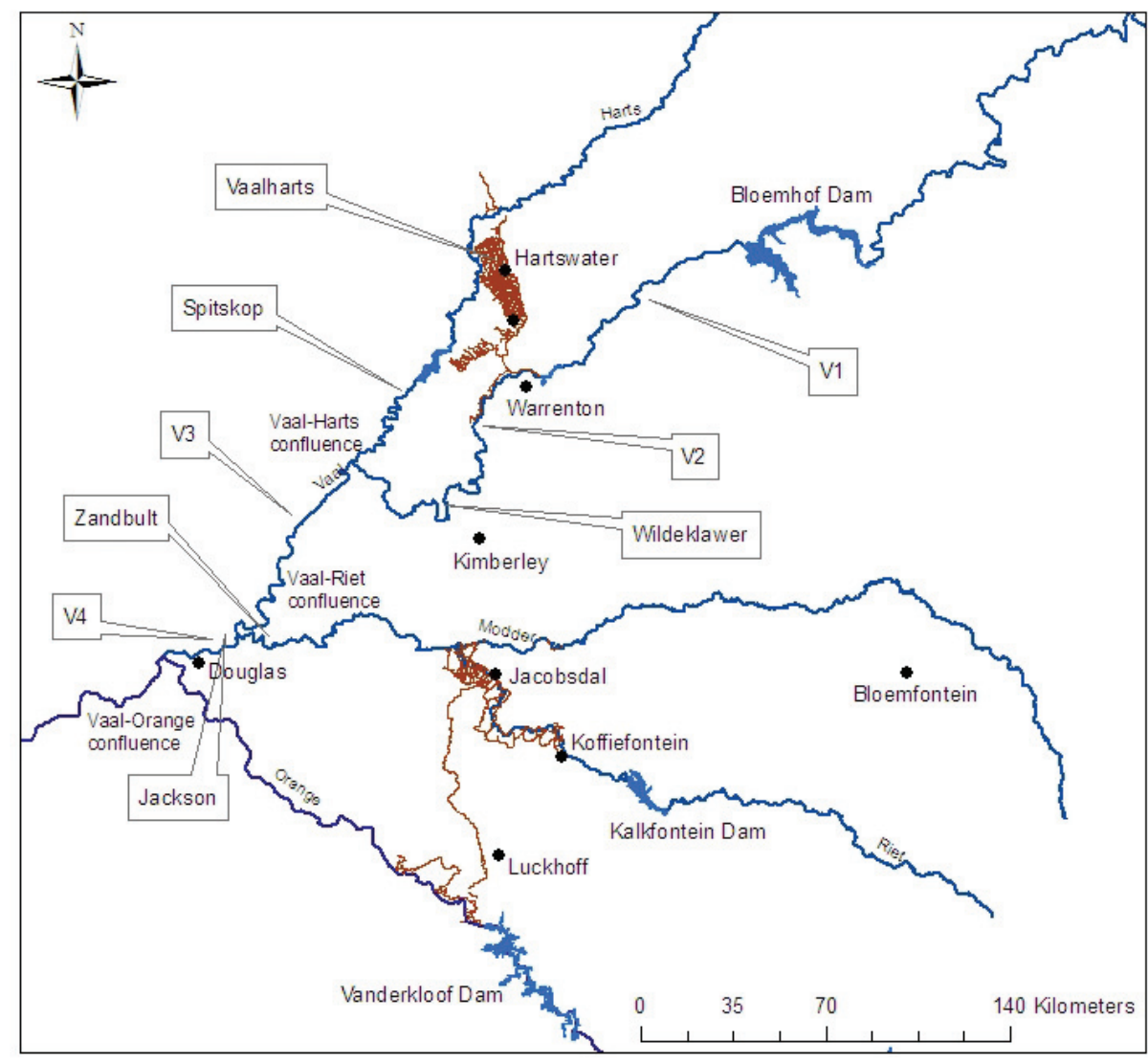

Figure 1

Map of the study area showing the river segments and selected sites

Delportshoop, downstream to the Vaal-Riet confluence, and V4: from the Vaal-Riet confluence downstream to the Vaal-Orange confluence. In each of these segments representative sites comprising irrigated and virgin soils were included in data selection for the prediction of salt balances. Relevant soil and water quality data reported by Du Preez et al. (2000) were used for this purpose. A general description of each study site, viz. Vaalharts, Spitskop, Wildeklawer, Zandbult and Jackson is given in Table 1.

\begin{tabular}{|c|c|c|c|c|c|}
\hline \multicolumn{6}{|c|}{$\begin{array}{c}\text { TABLE } 1 \\
\text { General description of the study sites }\end{array}$} \\
\hline Site* $^{*}$ & $\begin{array}{l}\begin{array}{l}\text { Soil } \\
\text { form }\end{array} \\
\end{array}$ & $\begin{array}{l}\text { Soil depth } \\
(\mathrm{m})\end{array}$ & \begin{tabular}{c|} 
Years \\
irrigated
\end{tabular} & $\begin{array}{l}\text { Irrigation } \\
\text { system }\end{array}$ & $\begin{array}{l}\text { Water table } \\
\text { depth }(\mathrm{m})\end{array}$ \\
\hline \multicolumn{6}{|l|}{ Vaalharts (V1) } \\
\hline Virgin sand & Hutton & 1.8 & 0 & None & None \\
\hline Irrigated sand & Bainsvlei & 1.8 & 53 & Flood & 1.6 \\
\hline Irrigated \& drained sand & Bainsvlei & 1.8 & 53 & Flood & 1.0 \\
\hline Virgin clay & Valsrivier & 1.6 & 0 & None & None \\
\hline Irrigated clay & Valsrivier & 1.6 & 53 & Flood & None \\
\hline \multicolumn{6}{|l|}{ Spitskop (V1) } \\
\hline Virgin clay & Arcadia & 1.2 & 0 & None & None \\
\hline Irrigated clay & Arcadia & 1.2 & 53 & Flood & None \\
\hline \multicolumn{6}{|l|}{ Wildeklawer (V2) } \\
\hline Virgin sand & Hutton & 1.6 & 0 & None & None \\
\hline Irrigated sand & Bainsvlei & 1.6 & 17 & Centre pivot & None \\
\hline Virgin sandy loam & Oakleaf & 1.8 & 0 & None & None \\
\hline Irrigated sandy loam & Oakleaf & 1.8 & 30 & Flood & None \\
\hline \multicolumn{6}{|l|}{ Zandbult (V3) } \\
\hline Virgin sand & Hutton & 2.0 & 0 & None & None \\
\hline Irrigated sand & Hutton & 2.0 & 19 & Centre pivot & None \\
\hline Virgin sandy loam & Oakleaf & 1.0 & 0 & None & None \\
\hline Irrigated sandy loam & Oakleaf & 1.0 & 29 & Flood & None \\
\hline \multicolumn{6}{|l|}{ Jackson (V4) } \\
\hline Virgin sand & Bloemdal & 1.6 & 0 & None & 1.3 \\
\hline Irrigated sand & Bloemdal & 1.6 & 45 & Centre pivot & 1.1 \\
\hline
\end{tabular}

*Soils were irrigated with water from the Vaal River segments as indicated in brackets.

**Soil Classification Working Group (1991) 
Numerous process-based models are available to simulate salt accumulation in soils and hence to predict expected crop response. Unfortunately, most of these models need daily inputs of irrigation which were not available for the soils studied along the lower Vaal River. It was decided therefore to estimate the salt balances of these soils with two empirical models, viz. the general salt balance of Aragües (1996) and the specific salt balance of Szabolcs (1986). Both models are based on mathematical functions that were fitted to experimental field observations (Jones et al., 1987).

\section{Aragües model}

The general salt balance of Aragües (1996) is presented in Eq. (1):

$$
\begin{aligned}
& C_{i} W_{i}-C_{d} W_{d}-M_{h c}+\left(M_{s p}-M_{s d}\right)+M_{i s}+M_{p r e}+M_{a f m} \\
& +M_{p r}+M_{i w r}-M_{d p}=0
\end{aligned}
$$

where:

$C_{i}=$ salt content of irrigation water $\left(\mathrm{mg} \cdot \ell^{-1}\right)$

$W_{i}=$ amount of irrigation water $\left(\ell \cdot \mathrm{ha}^{-1}\right)$

$C_{d}=$ salt content of drainage water $\left(\mathrm{mg} \cdot \ell^{-1}\right)$

$W_{d} \quad=$ amount of drainage water $\left(\ell \cdot \mathrm{ha}^{-1}\right)$

$M_{h c}=$ salt removal by harvesting of crops $\left(\mathrm{mg} \cdot \mathrm{ha}^{-1}\right)$

$M_{s p}=$ precipitation of salts in soil $\left(\mathrm{mg} \cdot \mathrm{ha}^{-1}\right)$

$M_{s d}^{s p}=$ dissolution of salts in soil $\left(\mathrm{mg} \cdot \mathrm{ha}^{-1}\right)$

$M_{i s}=$ initial amount of salts present in soil dissolved from natural mineral deposits $\left(\mathrm{mg} \cdot \mathrm{ha}^{-1}\right)$

$M_{\text {pre }}=$ salt mass in rainfall $\left(\mathrm{mg} \cdot \mathrm{ha}^{-1}\right)$

$\mathrm{M}_{\mathrm{afm}}=$ salts added by fertilisers and other amendments to soil $\left(\mathrm{mg}^{-} \mathrm{ha}^{-1}\right)$

$M_{p r}=$ salts removed by runoff due to rainfall $\left(\mathrm{mg} \cdot \mathrm{ha}^{-1}\right)$

$M_{i w r}^{p r}=$ salts removed by runoff due to irrigation $\left(\mathrm{mg}^{\mathrm{p}} \mathrm{ha}^{-1}\right)$

$M_{d p}^{i w r}=$ salt mass leached below root zone $\left(\mathrm{mg} \cdot \mathrm{ha}^{-1}\right)$

The following assumptions and calculations were made to obtain the various inputs summarised in Table 2 for the Aragües model (Eq. (1)) in order to estimate salt balances in irrigated soils with virgin soils as reference:

- Maize and wheat are the only two crops that were produced in rotation over the irrigation period as given by the farmer, viz. 2 maize crops and 1 wheat crop every 2 years

- The total grain yields during this period were calculated on the basis that the average grain yield of maize was 9000 $\mathrm{kg} \cdot \mathrm{ha}^{-1}$ and that of wheat $5000 \mathrm{~kg} \cdot \mathrm{ha}^{-1}$ annually

- An average water application of $600 \mathrm{~mm}$ per growing season through irrigation with no runoff was used to calculate the total amount of water applied for the irrigation period as given by the farmer

- In order to obtain the salt application through irrigation the average total dissolved solids (TDS) in the water of river segments V1 to V4 was calculated from the average electrical conductivity (EC) values reported by Du Preez et al. (2000), using a conversion factor of 6.5

- Salts applied through fertilisation amounted to 1 tha $^{-1}$ every cropping season

- Removal of salts by the crops was calculated as 5\% of the biomass that was removed from the field, viz. in the case of maize with a harvest index of 0.5 all the grain plus half of the residue and in the case of wheat only the grain

- Precipitation and dissolution of salts were negligible in the soils under investigation

- The salt content of a virgin soil is a reflection of the salt content of an irrigated soil before irrigation commenced

- The salt content of a soil was calculated with Eqs. (2) to (4) using the EC values of the profiles reported on by Du Preez et al. (2000).

$S=(C \times W) / 10^{9}$

$C=6.5\left(\sum_{\mathrm{x}=1}^{\mathrm{n}} E C / \mathrm{n}\right)$

$W=10000 \theta_{\text {sat }} D$

where:

$S=$ total salt content of soil $\left(\mathrm{t}^{-h} \mathrm{a}^{-1}\right)$ to a depth $D$

$C=$ average salt concentration in saturation extracts (mg $\cdot \ell^{-1}$ ) to a depth $D$

$W=$ total amount of water in saturated soil $\left(\ell \cdot \mathrm{ha}^{-1}\right)$ to a depth $D$

$E C=$ electrical conductivity of the saturation extracts from the $200 \mathrm{~mm}$ soil layers $\left(\mathrm{mS} \cdot \mathrm{m}^{-1}\right)$. In cases where the $E C$ of a deeper layer was not measured, the $E C$ of the overlying layer was used.

$n=$ number of soil layers to depth $D$

$\theta_{\text {sat }}=$ water content at saturation was calculated as $0.38 \mathrm{~mm} \cdot \mathrm{mm}^{-1}$ using an average bulk density of $1630 \mathrm{~kg} \cdot \mathrm{m}^{-3}$ (Bennie et al., 1988) irrespective of soil type, but a value of $0.35 \mathrm{~mm} \cdot \mathrm{mm}^{-1}$ was used to compensate for entrapped air

$D=$ soil depth $(\mathrm{mm})$ as given in Table 1

\section{Szabolcs model:}

The specific salt balance of Szabolcs (1986) is presented in Eq. (5):

$b=a\left[d+\left(c u / m t_{f s} \times 10^{5}\right)\right]$

where:

$b=$ soluble salt content of soil at end of observation period (mg.100 g ${ }^{-1}$ soil)

$a=$ soluble salt content of soil at beginning of observation period (mg $100 \mathrm{~g}^{-1}$ soil)

$d=$ salt regime coefficient of soil which represents the change in salt content during the observation period (mg.100 g-1 soil)

$c=$ salt content of irrigation water during observation period $\left(\mathrm{g} \cdot \ell^{-1}\right)$

$u=$ quantity of irrigation water applied during observation period $\left(\mathrm{m}^{3} \cdot \mathrm{ha}^{-1}\right)$

$m=$ volume of soil layer for which salt balance is estimated $\left(\mathrm{m}^{3} \cdot \mathrm{ha}^{-1}\right)$

$t_{\text {fs }}=$ bulk density of the soil $\left(\mathrm{kg} \cdot \mathrm{m}^{-3}\right)$

The following assumptions and calculations were made to obtain inputs (Table 3) for the Szabolcs model in order to estimate salt content and osmotic potential changes in irrigated soils from 1999 to 2049:

- It was assumed that no runoff resulted from irrigation, that precipitation and dissolution of salts in the soils were negligible, the salt content of a virgin soil represents the salt content of an irrigated soil before irrigation started and that the soils have an average bulk density of $1630 \mathrm{~kg} \cdot \mathrm{m}^{-3}$, irrespective of type. The values given in Table 2 concerning the total amount of water applied through irrigation, the TDS in the water of river segments V1 to V4 and the salt contents of the soils were used as input for the model. In the case of the latter two parameters, it was however necessary to convert 


\begin{tabular}{|c|c|c|c|c|c|c|}
\hline \multicolumn{7}{|c|}{$\begin{array}{c}\text { TABLE } 2 \\
\begin{array}{c}\text { Inputs used for the Aragües model to estimate salt balances in irrigated soils } \\
\text { with virgin soils as reference }\end{array}\end{array}$} \\
\hline Site $^{*}$ & $\begin{array}{l}\text { Average salt } \\
\text { content of } \\
\text { soil } \\
\left(\mathrm{mg} \cdot \ell^{-1}\right)\end{array}$ & $\begin{array}{l}\text { Average salt } \\
\text { content of } \\
\text { water } \\
\text { applied } \\
\left(\mathrm{mg} \cdot \ell^{-1}\right)\end{array}$ & $\begin{array}{c}\text { Total water } \\
\text { application } \\
\left(\ell \cdot \mathrm{ha}^{-1}\right) \times 1000\end{array}$ & $\begin{array}{l}\text { Total maize } \\
\text { grain yield } \\
\left(\mathrm{t} \cdot \mathrm{h} \mathrm{a}^{-1}\right)\end{array}$ & $\begin{array}{l}\text { Total maize } \\
\text { residue } \\
\text { removed } \\
\left(\mathrm{t} \cdot \mathrm{ha}^{-1}\right)\end{array}$ & $\begin{array}{l}\text { Total wheat } \\
\text { grain yield } \\
\left(\mathrm{t} \cdot \mathrm{ha}^{-1}\right)\end{array}$ \\
\hline \multicolumn{7}{|l|}{ Vaalharts (V1) } \\
\hline Virgin sand & 118 & & & & & \\
\hline Irrigated sand & 585 & 356 & 480000 & 477 & 239 & 135 \\
\hline Irrigated \& drained sand & 582 & 356 & 480000 & 477 & 239 & 135 \\
\hline Virgin clay & 839 & & & & & \\
\hline Irrigated clay & 552 & 356 & 480000 & 477 & 239 & 135 \\
\hline \multicolumn{7}{|l|}{ Spitskop (V1) } \\
\hline Virgin clay & 475 & & & & & \\
\hline Irrigated clay & 2803 & 356 & 480000 & 477 & 239 & 135 \\
\hline \multicolumn{7}{|l|}{ Wildeklawer (V2) } \\
\hline Virgin sand & 244 & & & & & \\
\hline Irrigated sand & 891 & 342 & 154000 & 153 & 77 & 45 \\
\hline Virgin sandy loam & 557 & & & & & \\
\hline Irrigated sandy loam & 453 & 342 & 272000 & 270 & 135 & 75 \\
\hline \multicolumn{7}{|l|}{ Zandbult (V3) } \\
\hline Virgin sand & 560 & & & & & \\
\hline Irrigated sand & 813 & 467 & 172000 & 171 & 86 & 50 \\
\hline Virgin sandy loam & 423 & & & & & \\
\hline Irrigated sandy loam & 605 & 467 & 263000 & 261 & 131 & 75 \\
\hline \multicolumn{7}{|l|}{ Jackson (V4) } \\
\hline Virgin sand & 997 & & & & & \\
\hline Irrigated sand & 394 & 519 & 408000 & 405 & 203 & 115 \\
\hline
\end{tabular}

the values to appropriate units, viz. $\mathrm{g} \cdot \ell^{-1}$ and $\mathrm{mg} \cdot 100 \mathrm{~g}^{-1}$.

- Removal of salts by the crops was not taken into account.

- The osmotic potential of a soil was calculated with Eq. (6) (Jurinak and Suarez, 1996) using the EC values of the profiles reported by Du Preez et al. (2000):

$$
\psi=0.4\left(\sum_{x=1}^{n} \mathrm{EC} / \mathrm{n}\right)
$$

where:

$\psi=$ average osmotic potential to the specified depth $(\mathrm{kPa})$

$E C=$ electrical conductivity of the saturation extracts from the $200 \mathrm{~mm}$ soil layers $\left(\mathrm{mS} \cdot \mathrm{m}^{-1}\right)$. In cases where the EC of a deeper layer was not measured, the EC of the overlying layer was used.

$n=$ number of soil layers to the specified depth.

\section{Results and discussion}

The salt balances estimated with the Aragües model for the soils at the different sites are presented in Table 4. As shown in Table 1 irrigation periods varied between 17 years at Wildeklawer and 53 years at Vaalharts and Spitskop. Addition of salts to the soils as a result of farming practices varied between 79 tha $^{-1}$ at Wildeklawer and $280 \mathrm{t} \cdot \mathrm{ha}^{-1}$ at Jackson, with irrigation water being the major contributor of salt. Fortunately, between $78 \%$ and $87 \%$ of the salts added to the soils had been leached from the root zone. In addition, the crops removed a significant amount of salts. The net result was a gain of 0.6 to $9.8 \mathrm{t}$ salts $\cdot \mathrm{ha}^{-1}$ in six soils and a loss of 0.6 to $3.4 \mathrm{t}$ salts ha $^{-1}$ in three soils.

Four of the 6 soils that gained salts are sandy (Table 4). The irrigated sands at Vaalharts and Wildeklawer were classified as a Bainsvlei form and that of Zandbult as a Hutton form
(Table 1). The internal drainage properties of these soils in combination with irrigation systems played an important role in the accumulation of salt in the root zone. For example, the Bainsvlei soil at Wildeklawer was irrigated with a centre pivot while flood irrigation was used on the Bainsvlei soil at Vaalharts. Despite the presence of the impermeable soft plinthic horizon of the Bainsvlei soil at Wildeklawer only the Bainsvlei soil at Vaalharts contained a water table at the time of sampling. This was attributed to over-irrigation associated with a less efficient flood irrigation system in use at Vaalharts. Water tables are seen as a forerunner of salinity (Ellington et al., 2004; Benyamini et al., 2005) and have resulted here in a salt gain of $3 t^{t} \cdot \mathrm{ha}^{-1}$ in both the undrained and drained sands. This result indicates that the harmful influence of the water table was not ameliorated by drainage. Comparing the increase of salt in the Bainsvlei soil at Vaalharts $\left(3 \mathrm{t}^{\left.\cdot h \mathrm{~h}^{-1}\right)}\right.$ and Wildeklawer (3.6 tha ${ }^{-1}$ ) illustrates another aspect of salt management. Centre pivots from this era were designed to supply just enough water to meet the peak water demand. Hence, the most likely way that salts could leach from the root zone was during periods of high rainfall, including flooding. It is however, expected that the soft plinthic horizon in the Bainsvlei soil would limit the effectiveness of this leaching process to some extent. This expectation is confirmed by the considerable lower salt increase (1.8 vs $3.6 \mathrm{t}^{\mathrm{h}} \mathrm{a}^{-1}$ ) on the deep, freely drained Hutton soil at Zandbult, on which a centre-pivot system was also used. The highest buildup of salts $\left(9.8 \mathrm{t}^{-} \mathrm{ha}^{-1}\right)$ occurred in the clay soil of the Arcadia form that was flood irrigated at Spitskop. This was expected as the soil contains swelling clays which restrict drainage and hence the leaching of salts (Le Roux et al., 2007). On the other hand the greatest loss of salt $\left(1.6 \mathrm{t} \cdot \mathrm{ha}^{-1}\right)$ was observed on the flood-irrigated duplex soil of the Valsrivier form at Vaalharts. Le Roux et al. (2007) described the morphology of the soil and 


\begin{tabular}{|c|c|c|c|c|}
\hline $\begin{array}{l}\text { Selected inputs used } \mathrm{f} \\
\text { indicating salt ce }\end{array}$ & $\begin{array}{l}\text { the Szabc } \\
\text { tent chang }\end{array}$ & $\begin{array}{l}\text { E } 3 \\
\text { del to estim } \\
\text { oils for the }\end{array}$ & $\begin{array}{l}\text { te salt regime } \\
\text { eriod being ir }\end{array}$ & $\begin{array}{l}\text { oefficients } \\
\text { gated }\end{array}$ \\
\hline Site $^{\star}$ & Salt conter & $\left(\mathrm{mg} \cdot 100 \mathrm{~g}^{-1}\right)$ & Average salt & Total water \\
\hline & Initial & Present & $\begin{array}{c}\text { content of } \\
\text { water applied } \\
\left(\mathrm{g} \cdot \mathrm{e}^{-1}\right)\end{array}$ & $\begin{array}{l}\text { application } \\
\left(\ell \cdot \mathrm{ha}^{-1}\right) \times 1000\end{array}$ \\
\hline Vaalharts (V1) & & & & \\
\hline Irrigated sand & 2.54 & 12.56 & 0.356 & 480000 \\
\hline Irrigated \& drained sand & 2.54 & 12.50 & 0.356 & 480000 \\
\hline Irrigated clay & 18.00 & 11.85 & 0.356 & 480000 \\
\hline Spitskop (V1) & & & & \\
\hline Irrigated clay & 10.21 & 60.18 & 0.356 & 480000 \\
\hline Wildeklawer (V2) & & & & \\
\hline Irrigated sand & 5.23 & 19.12 & 0.342 & 154000 \\
\hline Irrigated sandy loam & 11.96 & 9.73 & 0.342 & 272000 \\
\hline Zandbult (V3) & & & & \\
\hline Irrigated sand & 12.03 & 17.45 & 0.467 & 172000 \\
\hline Irrigated sandy loam & 9.07 & 12.98 & 0.467 & 262000 \\
\hline Jackson (V4) & & & & \\
\hline Irrigated sand & 21.41 & 8.46 & 0.519 & 408000 \\
\hline
\end{tabular}

*Soils were irrigated with water from the Vaal River segments as indicated in brackets.

\begin{tabular}{|l|c|c|c|c|c|c|c|c|}
\hline \multicolumn{7}{|c|}{ TABLE 4 } \\
Salt balances as estimated with the Aragües model in irrigated soils with virgin soils as reference
\end{tabular}

*Soils were irrigated with water from the Vaal River segments as indicated in brackets.

showed that it has better internal drainage properties than the Bainsvlei soil. The absence of a water table in the Valsrivier soil confirmed their observation. Despite the flood irrigation used on the two sandy loam soils of the Oakleaf form at Wildeklawer and Zandbult, no water tables were observed. Their salt content increased at Zandbult and decreased at Wildeklawer with the same amount, viz. 0.6 tha $\mathrm{a}^{-1}$.

As already mentioned, the Szabolcs model can be used to estimate the change in salt content of a soil if the salt regime coefficient is known. It was therefore necessary to calculate the salt regime coefficients to estimate the salt contents and hence the osmotic potentials of the soils in the year 2049 as indicated in Table 5.

The salt regime coefficients were all negative, indicating a net outflow of salts from the root zone for the period the soils were irrigated. Comparisons of these coefficients are complicated by the difference in irrigation periods. Nevertheless, at Vaalharts and Spitskop all the soils were irrigated for 53 years and it is clear that the outflow of salts from the clays exceeded that of the sands, especially at Spitskop. 


\begin{tabular}{|c|c|c|c|c|c|}
\hline \multicolumn{6}{|c|}{$\begin{array}{cc}\text { TABLE } 5 \\
\text { Salt content and osmotic potential changes in }\end{array}$} \\
\hline \multirow[t]{2}{*}{ Site* } & \multirow{2}{*}{$\begin{array}{c}\begin{array}{c}\text { Salt regime } \\
\text { coefficient } \\
\left(\mathrm{mg} \cdot 100 \mathrm{~g}^{-1} \cdot \mathrm{yr}^{-1}\right)\end{array} \\
\end{array}$} & \multirow{2}{*}{$\begin{array}{l}\text { Salt application } \\
\text { rate } \\
\left(\mathrm{mg} \cdot 100 \mathrm{~g}^{-1} \cdot \mathrm{yr}^{-1}\right)\end{array}$} & \multirow{2}{*}{$\begin{array}{l}\text { Salt content of } \\
\text { soil }\left(\mathrm{mg}^{\left.-100 \mathrm{~g}^{-1}\right)}\right. \\
2049\end{array}$} & \multicolumn{2}{|c|}{$\begin{array}{l}\text { Osmotic potential } \\
\text { of soil }(\mathrm{kPa})\end{array}$} \\
\hline & & & & 1999 & 2049 \\
\hline Vaalharts (V1) & & & & & \\
\hline Irrigated sand & -10.80 & 10.99 & 22.00 & -62 & -109 \\
\hline Irrigated \& drained sand & -10.80 & 10.99 & 21.90 & -62 & -108 \\
\hline Irrigated clay & -12.48 & 12.36 & 6.04 & -59 & -30 \\
\hline Spitskop (V1) & & & & & \\
\hline Irrigated clay & -15.54 & 16.48 & 107.33 & -298 & -531 \\
\hline Wildeklawer (V2) & & & & & \\
\hline Irrigated sand & -11.22 & 12.03 & 59.77 & -95 & -297 \\
\hline Irrigated sandy loam & -10.57 & 10.49 & 6.02 & -48 & -30 \\
\hline Zandbult (V3) & & & & & \\
\hline Irrigated sand & -12.83 & 13.12 & 31.70 & -86 & -157 \\
\hline Irrigated sandy loam & -25.95 & 26.08 & 19.72 & -64 & -98 \\
\hline Jackson (V4) & & & & & \\
\hline Irrigated sand & -18.33 & 18.04 & -5.93 & -42 & 0 \\
\hline
\end{tabular}

In order to predict the effect of salt accumulation for the year 2049 the assumption was made that the current irrigation practices will remain constant and so the estimated salt regime coefficients. Of the soils for which predictions were made, six will have a higher salt content and three of the soils will have a lower salt content compared to that in 1999 (Table 5). The expected changes in the salt content of the soils are in accordance with the salt gains and losses reported in Table 4. The salt content of the sands at Vaalharts, Wildeklawer and especially Zandbult will increase, while that at Jackson will decrease. In the case of the irrigated sandy loams a higher salt content is expected at Zandbult and at Wildeklawer a lower salt content in comparison to 1999. According to these estimations the salt content of the clay at Vaalharts will decrease and at Spitskop the salt content of the clay will increase. The reasons for the expected changes in salt content are similar to that explained for the gains and losses of salts in Table 4.

The change of osmotic potentials is in accordance with the salt contents in Table 5, indicating a decrease in the osmotic potential of the root zone in six of the sites compared to 1999. The osmotic potential ranged from $-98 \mathrm{kPa}$ to $-531 \mathrm{kPa}$ over the sites. Ehlers et al. (2007) showed that an increase in salinity leads to a linear decrease in the total seasonal evapotranspiration (ET) of both maize and wheat. Applying the predicted osmotic potential values of the six sites to the ET vs. osmotic potential equations of Ehlers et al. (2007), indicates that the seasonal ET of maize is more affected than that of wheat. Accordingly, a $10 \%$ decrease in the seasonal ET is expected when the soil solution reaches osmotic potential values of lower than $-100 \mathrm{kPa}$ and $-280 \mathrm{kPa}$ for maize and wheat yields, respectively. The osmotic potential of $-530 \mathrm{kPa}$ predicted for the Spitskop site reflects the worst case scenario. Under these conditions it is expected that the ET of maize will be reduced by about $50 \%$ in relation to a non-saline stress treatment, while that of wheat with only 20\%. Stewart et al. (1977) are of opinion that salinity induced plant water stress has the same negative effect on yield as drought induced plant water stress. A reduction in ET of this magnitude, will impact negatively on sustaining economical yields. Fortunately, in most cases the negative impact can be avoided through the introduction of proper salinity management strategies as suggested by Rhoades (1997) and Hillel (2000). The results also suggest that the irrigation of clay soils with swelling properties, such as the Arcadia soil at the Spitskop site, should be avoided with water quality and drainage conditions similar to those at Spitskop.

\section{Conclusions}

The result of salt additions to croplands by irrigation farming practices along the lower Vaal River system and the impact thereof on the osmotic potential of soils over the long term were estimated with the aid of salt-balance models. These models have some shortfalls as they, e.g. do not accurately address the differential decline in water use by crops as the soils become saline and hence freeing more water for leaching. Despite of such shortfalls provide the predictive outcomes of the models useful insight on salinity changes in irrigated soils.

Nine soils were included in the study and they had been irrigated for periods of between 17 to 53 years. Over these periods the net result was a gain of 0.6 to $9.8 \mathrm{t}$ salts $\cdot \mathrm{ha}^{-1}$ in 6 soils and a loss of 0.6 to 3.4 t salts.ha ${ }^{-1}$ in 3 soils. Some of these gains and losses have been explained with the internal drainage characteristics of the soils in combination with the irrigation systems that are used on them. Predictions showed that if the current practices are sustained for the next 50 years the osmotic potential of 6 soils will decline to below the threshold of $-100 \mathrm{kPa}$ for maize. In two of these soils the threshold of $-280 \mathrm{kPa}$ for wheat will also be exceeded. Hence salt-induced water stress could reduce the yield of maize and even wheat significantly in future if appropriate precautionary measures are not introduced.

The models revealed that the ultimate fate of salts that enter a soil through irrigation farming practices is site specific. A set of measures will be needed therefore to manage salinity in the root zone of a soil at levels that are not harmful for crops. This aspect warrants proper investigation to ensure sustainable cropping in the study area.

\section{Acknowledgements}

The Water Research Commission, Pretoria, South Africa, is gratefully acknowledged for the financial support of this study. Our sincere appreciation to all the farmers for their kind cooperation and to Malcolm Hensley at the University of the Free State for editorial revision. 


\section{References}

ADDISCOT TM and WAGENET RJ (1985) Concepts of solute leaching: A review of modelling approaches. J. Soil Sci. 85 411-424.

ARAGÜES RM (1996) Conceptual irrigation return flow hydrosalinity model. In: KK Tanji (ed.) Agricultural Salinity Assessment and Management. Am. Soc. of Civ. Eng., New York.

BARNARD RO, RETHMAN NFG, ANNANDALE JG, MENTZ W and JOVANOVIC NZ (1997) The Screening of Crop, Pasture and Wetland Species for Tolerance of Polluted Water Originating in Coal Mines. WRC Report No. K5/582. Water Research Commission, Pretoria, South Africa.

BENNIE ATP, COETZEE MJ, VAN ANTWERPEN R, VAN RENSBURG LD and BURGER R DU T (1988) A Water Balance Model for Irrigation based on Profile Water Supplying Rate and Crop Water Requirement (In Afrikaans). WRC Report No. 144/88/1. Water Research Commission, Pretoria, South Africa.

BENYAMINI Y, MIRLAS V, MARISH S, GOTTESMAN M, FIZIK E and AGASSI M (2005) A survey of soil salinity and groundwater level control systems in irrigated fields in the Jezréel Valley, Israel. Agric. Water Manage. 76 181-194.

CLARKE RT (1973) A review of some mathematical models used in hydrology, with observations on their calibration and use. J. Hydrol. 19 1-20.

DE ROOY NM (1991) Mathematical Simulation of Bio-Chemical Processes in Natural Waters by the Model CHARON. Institute of Hydrodynamics and Hydraulic Engineering, Technical University of Denmark, Denmark.

DU PREEZ CC, STRYDOM MG, LE ROUX PAL, PRETORIUS JP, VAN RENSBURG LD and BENNIE ATP (2000) Effect of Water Quality on Irrigation Farming along the lower Vaal River: The Influence on Soils and Crops. WRC Report No. 740/1/00. Water Research Commission, Pretoria, South Africa.

EHLERS L, BARNARD JH, DIKGWATLHE SB, VAN RENSBURG LD, CERONIO GM, DU PREEZ CC and BENNIE ATP (2007) Effect of Irrigation Water and Water Table Salinity on the Growth and Water Use of Selected Crops. WRC Report No. 1359/1/07. Water Research Commission, Pretoria, South Africa.

ELLINGTON RG, USHER BH and VAN TONDER GJ (2004) Quantification of the Impact of Irrigation on the Aquifer Underlying the Vaalharts Irrigation Scheme. WRC Report No. 1089/1/03. Water Research Commission, Pretoria, South Africa.

FELMY AR, GIRVIN DC and JENNE EA (1984) MINTEQ - A Computer Program for Calculating Aqueous Geochemical Equilibria. US Environmental Protection Agency, Athens, Georgia.

FLOWERS RJ and YEO AR (1986) Ion relations of plants under drought and salinity. Aust. J. Plant Physiol. 13 75-91.

HANKS RJ, NIMAH MN and CUI JK (1991) Model SOWATSAL. SoilPlant-Atmosphere-Salinity Management Model (User's Manual).
Plant, Soils and Biometeorology Dept., Utah State University, Logan, Utah.

HILLEL D (2000) Salinity Management for Sustainable Irrigation Integrating Science, Environment and Economics. The World Bank, Washington, D.C.

JONES JW, MISHOE JW and BOOTE KJ (1987) Introduction to Simulating and Modelling. Technical Bulletin 100, University of Florida, Gainesville, Florida.

JURINAK JJ and SUAREZ DL (1996) The chemistry of salt-affected soils and water. In: KK Tanji (ed.) Agricultural Salinity Assessment and Management. Am. Soc. of Civ. Eng., New York.

LE ROUX PAL, DU PREEZ CC, STRYDOM MG, VAN RENSBURG LD and BENNIE ATP (2007) Effect of irrigation on soil salinity profiles along the lower Vaal River, South Africa. Water SA 33 473478.

REEVES RC (1957) The relation of salinity to irrigation and drainage requirements. Proc. $3^{\text {rd }}$ Congr. of Int. Comm. on Irrig. and Drainage. San Francisco, California.

RHOADES JD (1997) Sustainability of Irrigation: An Overview of Salinity Problems and Control Strategies. US Salinity Laboratory, Riverside, California.

SOIL CLASSIFICATION WORKING GROUP (1991) Soil classification - A Taxonomic System for South Africa. Memoirs on the Agricultural Natural Resources of South Africa No. 15. Department of Agricultural Development, Pretoria, South Africa.

STEWART JL, DANIELSON RE, HANKS RJ, JACKSON EB, HAGON RM, PRUIT WO, FRANKLIN WT and RILEY JP (1977) Optimizing Crop Production through Control of Water and Salinity Levels in the Soil. Utah Water Research Laboratory Progress Report No. 151, Logan, Utah.

SZABOLCS I (1986) Agronomical and ecological impact of irrigation on soil and water salinity. Adv. Soil. Sci. 4 189-218.

VERBURG K, ROSS PJ and BRISTOW KL (1996) SWIMV2.1. User Manual. CSIRO Division of Soils, Australia.

WAGENET RJ and HUTSON JL (1987) LEACHM - A Process Based Model of Water and Solute Movement, Transformations, Plant Uptake and Chemical Reactions in the Unsaturated Zone, Version 1.0. Department of Agronomy, Cornell University, Ithaca, New York.

WAGENET RJ and RAO PSC (1990) Modelling pesticide fate in soils. In: HH Cheng (ed.) Pesticides in the Soil Environment: Processes, Impacts and Modelling. Soil Sci. Soc. of Am., Madison, Wisconsin.

WESTALL JC, ZACHARY JL and MOREL FMM (1976) MINEQL: A Computer Program for the Calculation of Chemical Equilibrium Composition of Aqueous Systems. Tech. Note 1, Dept. Civil Eng., MIT, Cambridge.

WOLERY TJ (1983) EQ3NR: A Computer Program for Geochemical Aqueous Speciation - Solubility Calculations. Lawrence Livermore Laboratory, California. 
Available on website http://www.wrc.org.za ISSN 0378-4738 = Water SA Vol. 34 No. 1 January 2008 ISSN 1816-7950 = Water SA (on-line) 